\title{
Law of restitution
}

\section{Abolition of the rule that moneys paid under a mistake of law cannot be recovered}

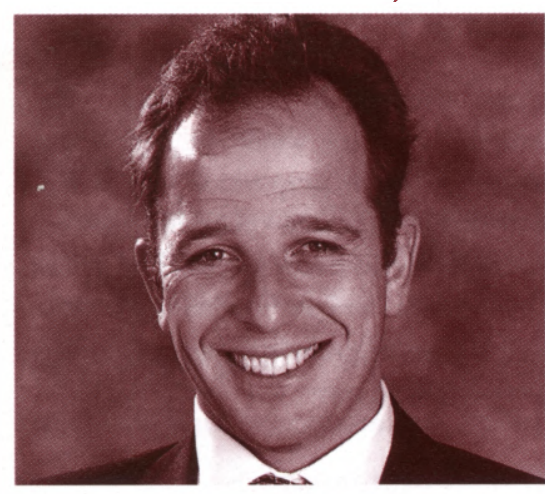

Michael Hales

In October 1998, the House of Lords overturned the rule of law that payments made under a mistake of law are irrecoverable - a rule that had stood for over 200 years. This landmark decision (Kleinwort Benson Ltd v Lincoln City Council [1998] 3 WLR 1095) has attracted much attention as it has the potential to create a flood of litigation over transactions which were completed many years ago.

\section{FACTS}

Kleinwort Benson entered into a number of interest rate swap agreements with various local authorities. At the time, both Kleinwort Benson and the local authorities believed the agreements to be valid and binding on the local authorities. It was subsequently established in Hazell $v$ Hammersmith \& Fulham London Borough Council [1990] 3 All ER 33 that these contracts were void because the local authorities did not have the necessary statutory powers to enter into such contracts.

As a result of the Hazell decision, Kleinwort Benson wanted to recover the sums paid to the local authorities. Where such payments had been made less than six years previously, Kleinwort Benson were able to recover them on the basis that there had been total failure of consideration, as these claims fell within the limitation period. The date of the decision in Hazell was irrelevant to these claims in so far as calculating the limitation period was concerned. Time started to run for bringing a claim in the usual way, i.e. from the date of payment.

\author{
by Michael Hales
}

Payments which had been made more than six years prior to the Hazell decision were assumed to be time barred on the basis of the law as it then stood.

In cases of mistake, the limitation period does not start to run until the mistake is discovered (or with reasonable diligence could be discovered) (s. 32(1)(c) of the Limitation Act 1980). However, it had long been established that payments made under a mistake of law, as opposed to fact, were irrecoverable.

Kleinwort Benson challenged this principle. Kleinwort Benson brought proceedings against four local authorities, on the grounds that the payments were made under a mistake of law and that the limitation period did not begin to run against them until the mistake was discovered, i.e. the date of the decision in Hazell. At first instance, Kleinwort Benson failed as the court was bound by Court of Appeal authority. However, leave was given to appeal directly to the House of Lords and their Lordships were invited to determine:

(a) whether or not Kleinwort Benson's claim established a cause of action in mistake of law; and

(b) if it did, whether Kleinwort Benson could rely on s. 32(1)(c) of the Limitation Act 1980.

By a majority decision, the House of Lords decided both points in Kleinwort Benson's favour. This article will examine the reasoning behind their Lordship's judgment.

\section{BACKGROUND TO THE RULE}

In Bilbie v Lumley (1802) 2 East 469 it was held that there is no right of recovery for sums paid under a mistake of law. Lord Ellenborough in his judgment said:

'Every man must be taken to be cognisant of the law; otherwise there is no saying to what extent the excuse of ignorance might not be carried. It would be urged in almost every case.'

This decision was followed in the case of Brisbane v Dacres (1813) 5 Taunt 143, 155-157, although the decision in Bilbie $\checkmark$ Lumley was challenged and full arguments were heard on the question of whether or not a mistake of law should permit recovery. The majority held that there was no right of recovery under a mistake of law, but did not reach this finding on the ignorantia juris non excusat maxim, invoked by counsel. In essence, the reason behind the court's decision was one of policy: where a demand is paid vountarily with full knowledge of the facts on which the payment is demanded, it cannot later be recovered, even if the payer's opinion of the law might later be different. The court's view was that a ruling to the contrary could result in great inconvenience. It considered that a defendant who receives a demand relating to a matter on which the law was unclear could choose whether or not to litigate the matter or pay the demand; if he paid, the transaction was closed.

\section{CRITICISM OF THE RULE}

After Brisbane v Dacres the rule became hardened over time. This led to criticisms and discussions about its reform. The main criticisms were perceived as follows:

(a) It allowed the payee to retain a payment which he would not, but for the mistake, have been entitled to, whereas justice appeared to demand that the sum should be repaid unless there were special circumstances justifying its retention.

(b) The distinction between mistakes of law and mistakes of fact produced results which appeared to be capricious. This was also true of the exceptions and qualifications to which the rule became subject.

(c) As a result of the difficulty in drawing a distinction in certain cases between mistakes of law and fact, and the temptation for judges to manipulate that distinction in order to achieve practical justice, the rule 
was uncertain and unpredictable in its application.

\section{FURTHER ARGUMENTS FOR ABROGATION}

The rule had been rejected in countries throughout the common law world as a result of academic work on the subject and the effect of two fundamental changes in the law:

- recognition that a coherent law of restitution founded on the principle of unjust enrichment exists; and

- recognition, within that law, of the defence of change of position.

Both of these doctrines had been accepted by the English courts in Lipkin Gorman v Karpnale Ltd [1991] 2 AC 548. Lord Goff considered that once this had happened, it was inevitable that the mistake of law rule should be abrogated or reformulated to allow recovery for mistakes of law and fact, subject to appropriate defences. The old rule could not survive but the law needed also to evolve appropriate defences to protect parties where a repayment would be unjust.

A comparison of the law of several other jurisdictions revealed that there was no necessity for a general exclusion of a right to recover under a mistake of law and the experience of those other systems served to dispel the fears expressed in English cases that the existence of a right to recover might lead to a flood of litigation.

\section{THE DECISION}

The majority of the Lords considered that the matter should not be postponed for legislation. Despite the Law Commission's recommendation for legislation in this area, there was no indication of when this would occur and that recommendation had itself been made because of the uncertainty as to when the matter would come before the House of Lords. By a 3-2 majority their Lordships held that the rule that moneys paid pursuant to a mistake of law were not recoverable no longer forms part of English law.

\section{FURTHER ISSUES CONSIDERED}

The House of Lords also considered the following issues.

\section{Payments under a settled understanding}

It is this issue, coupled with the limitation point, which has given rise to the concerns expressed in recent publications. The question which their Lordships considered was whether or not a payment made on the basis of a settled understanding of the law should be recoverable if that law was subsequently changed by judicial decision.

The facts of the case gave rise to precisely this situation. The parties believed the contracts to be valid and that the payments were therefore lawfully due. Following Hazell, this was shown to be incorrect. The local authorities argued for these circumstances to provide a defence and relied upon the Law Commission's recommendations to this effect.

The Lords considered the declaratory theory of judicial decisions. Judges interpret and thereby develop the law according to their understanding of it. This understanding is derived from statute, precedents, academic writings and reported cases. Judicial decisions are therefore retrospective in effect. The law as declared by the judge is treated as always having had that effect. Therefore, the payments made by Kleinwort Benson, whilst believed to be lawfully due when made, were in fact made under a mistake of law, as the law at that date was later clarified in Hazell.

Changes in the law made by new legislation, however, do not take effect retrospectively unless the instrument specifically so provides.

Despite the Law made by Commission's recommendations that the principle of payment under a settled understanding of the law should form an exception to the rule on recoverability, the majority of the House of Lords felt that the matter should be left to future legislation. There were insufficient grounds for them to impose such a restriction on the right to recover now. They also considered that the defences which would be available would adequately protect those parties where a repayment would be unjustified.

\section{Honest payment}

Is it a defence to a claim for restitution of money paid under a mistake of law that the defendant honestly believed that he or she was entitled to receive or retain?
This principle was proposed by Brennan J in David Securities Pty Ltd V Commonwealth Bank of Australia (1992) 175 CLR 353, 399 with a view to providing stability for concluded transactions.

Lord Goff, who delivered the leading judgment, considered that this proposition was too far-reaching. If it was accepted, the other defences would cease to have any practical relevance and, in cases where both parties shared the mistake, recovery would be barred. By starting with the proposition that money paid under a mistake is recoverable on the ground that its receipt will lead to the defendant's unjust enrichment, this defence would exclude recovery in a large proportion of cases.

\section{Completed transactions}

This issue arose from a footnote to an article written by Professor Birks entitled 'No consideration: Restitution after Void Contracts' (1993) 23 University of Western Australia Law Review 195, which suggested that recovery of money paid under a void contract should not be recoverable on the ground of mistake of law once the contract was fully performed.

On analysis of the proposition, the Lords considered that the effect of this would be that whilst a payer making a series of payments under a contract would have a right of recovery accruing in respect of each payment on the date that each payment was made, once the final payment was made the payer would lose his right to recover not only the final payment, but also all previous payments.

Counsel for Kleinwort Benson argued that this proposition was incompatible with the ultra vires rule that an ultra vires transaction should become binding simply because it has been completed. If Professor Birks' interpretation were correct, the result would be to give effect to a contract which public policy had declared void. This proposal was therefore rejected.

\section{Does s. 32(1)(c) apply?}

This section merely refers to 'mistake' and does not specify the type of mistake. It was recognised that by finding that the section applies equally to mistakes of law as to those of fact a cause of action could be extended indefinitely. Lord Goff specifically mentioned that this area may require legislative reform to limit the 
time for bringing claims in such cases, indicating that the Law Commission might want to address this urgently in light of the decision. Clearly, their Lordships anticipated the possibility of a flood of litigation arising from the case, although they declined to impose any restrictions on that possibility in their judgment, considering that the defences available should be sufficient until the matter was addressed by legislation.

\section{Defences}

Lord Goff mentioned two defences to claims for recovery of moneys paid under a mistake of law. These were:

(a) change of position; and

(b) settlement or compromise of an honest claim.

He also stated that defences would evolve as this area of the law developed. However, as neither of these defences was relevant to the case they received no detailed consideration.

The change of position defence was accepted in principle by the House of Lords in Lipkin Gorman $v$ Karpnale. It is available where a defendant, acting in good faith, has changed his position with the result that he or she would suffer an injustice if required to repay the moneys. The circumstances should be such that the injustice to the innocent recipient is greater than the injustice caused by denying restitution. The recipient would have a defence to the extent of his change of position. Thus, he might be required to repay to the claimant any moneys still retained by him. Expenditure of the moneys is not, of itself, sufficient to give rise to the defence, because the expenditure might have arisen in the ordinary course of events, regardless of the unjust enrichment. It seems therefore that the expenditure has to be caused by the enrichment for the defence to be available.

The defence of compromise of an honest claim is less well defined. The principle underlying this defence seems to be that, in agreeing to compromise a claim, payers are waiving their rights to investigate the merits of the claim and to ascertain their true legal rights. The payer is thereby taken to have assumed the risk of making a mistake of law or fact in agreeing to the compromise.

\section{Subsequent developments}

One other case concerning the recovery of money paid under a mistake of law has now come before the courts. This was Nurdin and Peacock plc v D B Ramsden and Co Ltd [1999] All ER 941. In that case the defendant tried to develop causation arguments which differentiated between various types of mistake of law. However, the court rejected this as too narrow an approach. The simple question to be answered was: would the payment have occurred if the payer had not made the mistake of law and, possibly, was the mistake directly connected to the overpayment and/or to the relationship between the payer and payee?

\section{Floodgates?}

The floodgates argument arises from the fact that payments made under a settled understanding of the law are now recoverable if that law is later changed by judicial decision, for a period of six years from the date of the relevant decision, i.e. being the date on which the mistake was or could be discovered. This could potentially give rise to a flood of litigation in respect of matters which are otherwise substantially outside any limitation period. However, the longer the period between completion of the relevant transaction and the change in the law, the more likely it may be that a defence of change of position would succeed.

Generally, the impact of the decision may be curbed by the following factors:

(a) The limitation period for claims arising under a mistake is governed by s. $32(1)(c)$ of the Limitation Act 1980, mentioned above. Abolition of the mistake of law rule does not start time running for all payments ever made under a mistake of law; it merely establishes that such a claim can now be made. If the mistake which induced the payment was discovered more than six years ago, a claim for recovery will be statutebarred.

(b) In many cases, the defence of change of position, or the defence of settlement or compromise of an honest claim, will preclude recovery.

(c) The House of Lords expects that further defences will evolve in this area of the law.
Michael Hales

Partner, Nabarro Nathanson

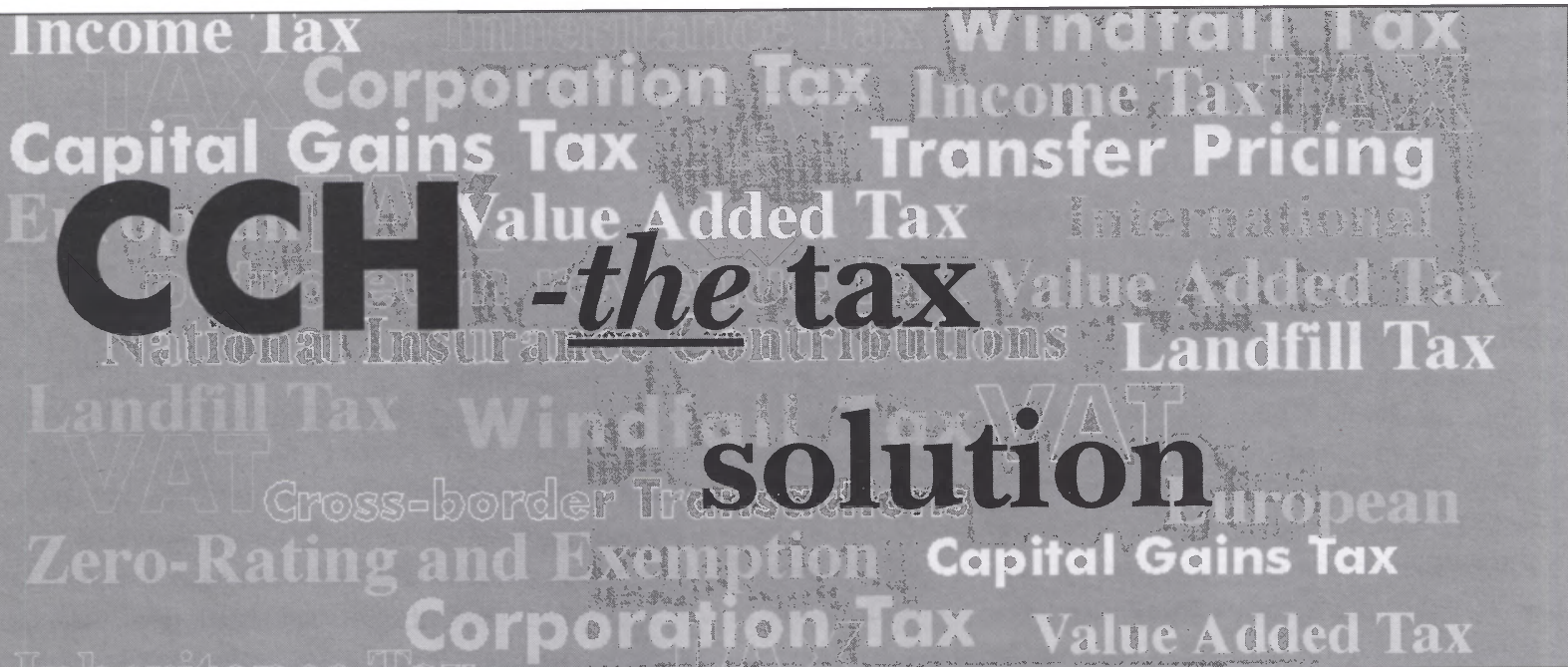

